\title{
Boron trifluoride etherate in organic synthesis
}

\begin{abstract}
The Lewis acid boron trifluoride etherate has played an important role in organic synthesis. To accomplish the hydroxylation of double bond, cleavage of epoxides, esterification of acids and many cyclization reaction boron trifluoride etherate proved very useful compared to other Lewis acids. These organic reactions are frequently employed to achieve the synthesis of natural products. In addition, boron trifluoride etherate has also been utilized to realize ketalization, thioketalization, alkylation and many others organic reactions.
\end{abstract}

Keywords: boron trifluoride etherate, hydroboration-oxidation, epoxides, esterification, thioketalization, cyclization
Volume 3 Issue I - 2019

\author{
Ajoy K Banerjee,' Alexis Maldonado,' Dioni \\ A Arrieche,' Liadis Bedoya,' William JVera,' \\ Elvia V Cabrera, ${ }^{2}$ Po S Poon ${ }^{3}$ \\ 'Chemistry Center,Venezuelan Institute of Scientific Research \\ (IVIC), Venezuela \\ ${ }^{2}$ Faculty of Chemical Engineering, Central University of Ecuador, \\ Quito, Ecuador \\ ${ }^{3}$ Technological Development Unit (UDT), University of \\ Concepcion, Chile
}

Correspondence: Ajoy K Banerjee, Centro de Química, IVIC, Apartado- 21827, Caracas-1020A, Venezuela, Tel +5802 1250 4| 32 4, Fax+5802 I250 4135 0, Email aabanerje@gmail.com

Received: November 06, 2018 | Published: January 21, 2019

\section{Introduction}

The innumerable application of boron trifluoride etherate in organic synthesis ${ }^{1,2}$ encouraged us to write a micro review on this reagent. The commercially available boron trifluoride etherate (b.p. $126^{\circ} \mathrm{C}$ ), a brown liquid, is very toxic by inhalation, causes severe burns, reacts violently with water, hot alkali or alkaline earth (not $\mathrm{Mg}$ ) metals with incandescence. It can be purified by distillation. This review would discuss only four principal use of boron trifluoride etherate: (a) hydroboration-oxidation reaction, (b) cleavage and rearrangement of epoxides, (c) esterification (d) cyclization. In addition, some other minor uses of boron trifluoride etherate will be briefly described.

\section{Applications of boron trifluoride etherate}

\section{Hydroboration-oxidation reaction}

The cis addition of diborane to an alkene bond provides an extremely useful method of hydration. Diborane can be generated by the addition of sodium borohydride to boron trifluoride etherate in tetrahydrofuran or ether at $0^{\circ}-5^{\circ} \mathrm{C}$. Diborane is the dimer of borane $\left(\mathrm{BH}_{3}\right)$ and is stable form of this reagent (Scheme1).

$$
\mathrm{NaBH}_{4}+\mathrm{BF}_{3} \underset{0-5{ }^{\circ} \mathrm{C}}{\longrightarrow} \mathrm{B}_{2} \mathrm{H}_{6}
$$

Scheme I Obtention of Diborane from sodium borohydride

The addition of diborane to the alkene is extremely rapid and generally, the reagent adds from the less hindered of the two faces of the $\pi$ system. The cis addition has been rationalized by a four center transition state. The borane complex resulting from the addition of diborane to an alkene is converted, with retention of stereochemistry, to an alcohol by treatment with basic hydrogen peroxide. Thus 1-methylcyclohexene 1 on hydroboration-oxidation leads the formation of trans-2-methylcyclo-hexanol 2. The mechanistic path has been depicted in (Scheme 2). The method for the conversion of alkene to alcohol by hydroboration-oxidation has been applied for the synthesis of many natural products. Few examples are illustrated below.

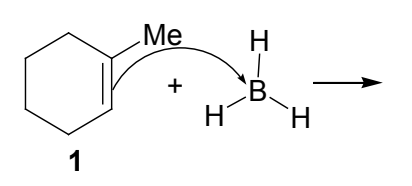<smiles></smiles><smiles>CC1(C)CCCCC1[BH2-]CO[N+](=O)[O-]</smiles><smiles></smiles><smiles>[B]OC1CCCCC1C</smiles><smiles>OCCO</smiles><smiles>CC1CCCCC1O[B]CCO</smiles><smiles>CC1CCCCC1O</smiles><smiles>CC1CCCCC1O</smiles>

2

Scheme 2 Reaction mechanism for the formation to trans-2-methylcyclohexanol 2

\section{Synthesis of $( \pm)$ junenol and $( \pm)$ acalomone}

The use of hydroboration-oxidation reaction was observed by Banerjee and coworkers during the synthesis ${ }^{3}$ of eudesmone sesquiterpenes $( \pm)$ junenol and $( \pm)$ acalomone. In order to achieve the synthesis of these sesquiterpenes the alkene 3 , was selected as starting material and subjected to hydroboration-oxidation to yield the alcohol 4 (Scheme 3). Ketone 5, obtained by the oxidation of the alcohol with Jones reagent ${ }^{4}$ was made to react with diethyl carbonate. The resulting product was treated with methyl lithium to obtain the ketol 6 whose conversion to the isopropyl ketone 7 was effected by dehydration 
and hydrogenation respectively. Metal hydride reduction of the ketone followed by oxidation with lead tetraacetate ${ }^{5}$ in cyclohexane afforded the cyclic ether 8 , which was converted to ketoacid 9 by oxidation with chromic acid and acetic acid. Decarboxylation with lead tetraacetate in benzene and pyridine followed by purification over $10 \% \mathrm{AgNO}_{3}$ impregnated silica gel afforded $( \pm)$ acolamone 10 Reduction of acolamone 10 with sodium borohydride in methanol, followed by sublimation of the resulting product yielded junenol 11 .

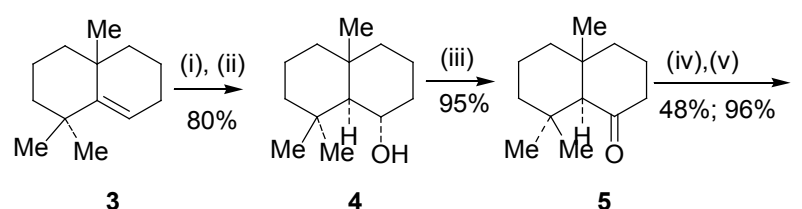<smiles>CC(C)C1CCC2(C)CCCC(C)(C)C2C(=O)C1C(C)C</smiles>

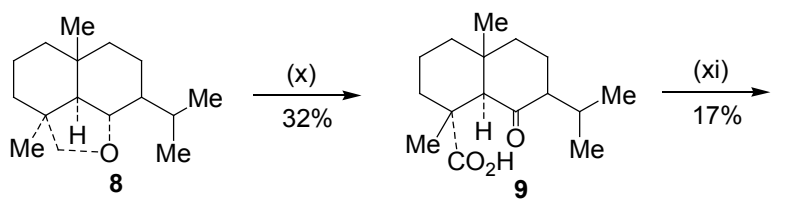<smiles>C=C1CCCC2(C)CCC(C(C)C)C(=O)C12</smiles>

10<smiles>C=C1CCCC2(C)CCC(C(C)C)C(O)C12</smiles>

11
Scheme 3 Synthesis of eudesmone sesquiterpenes $( \pm)$ junenol and $( \pm)$-acalomone

Reagents: (i) $\mathrm{BF}_{3} \cdot \mathrm{Et}_{2} \mathrm{O}, \mathrm{NaBH}_{4}, \mathrm{THF}, 0-5^{\circ} \mathrm{C}$; (ii) $\mathrm{NaOH}$ (I0\%), $\mathrm{H}_{2} \mathrm{O}_{2}(30 \%$ ); (iii) $\mathrm{CrO}_{3} / \mathrm{HMPT}$; (iv) $\mathrm{NaH}, \mathrm{CO}(\mathrm{OEt})_{2}$, DME; (v) MeLi, Et ${ }_{2} \mathrm{O}$, reflux, 2h; (vi) $\mathrm{HCl}$ (conc), $\mathrm{MeOH}$; (vii) $\mathrm{H}_{2}, \mathrm{PtO}_{2}, \mathrm{MeOH}$; (viii) $\mathrm{Na}$, EtOH, reflux; (ix) $\mathrm{Pb}(\mathrm{OAc}$ ), $\mathrm{C}_{6} \mathrm{H}_{12} ;$ (x) $\mathrm{CrO}_{3}, \mathrm{AcOH}$; (xi) $\mathrm{Pb}(\mathrm{OAc})_{4}, \mathrm{C}_{6} \mathrm{H}_{6}$, Py, reflux; (xii) $\mathrm{NaBH}_{4}, \mathrm{EtOH}$.

\section{Synthesis of pisiferic acid}

The use of hydroboration-oxidation has been recorded during the synthesis of pisiferic acid, ${ }^{6}$ a tricyclic diterpene which shows antibacterial activities against all gram-positive bacteria tested. ${ }^{7}$ The synthetic route has been depicted in Scheme 4. Hydroborationoxidation of the alkene 13, prepared from the known ${ }^{8}$ ketoalcohol 12 , was oxidized with jones reagent $t^{4}$ and reduced respectively with metal hydride to give alcohol 14 . Oxidation with lead tetraacetate in benzene with $250 \mathrm{~W}$ tungsten lamp gave the cyclic ether 15 . The cleavage of the cyclic ether with zinc, zinc iodide and acetic acid8 furnished pisiferol 16. The transformation of the pisiferol to the ester 17 was achieved in six steps:
(i) Methylation with dimethyl sulfate
(ii) Oxidation with jones reagent
(iii) Esterification with diazomethane
(iv) Reduction with sodium borohydride
(v) Tosylation
(vi) Detosylation

The ester 17 was converted into pisiferic acid 18 by heating with aluminium bromide and ethane thiol.

The hydroboration-oxidation reaction has been applied for the synthesis of $( \pm)$ eudes-4(14),7(11)-diene-8-one, ${ }^{9}$ taxodione, ${ }^{10}$ norditerpene alcohols ${ }^{11}$ and many other terpenes. ${ }^{12}$ These examples clearly indicate the use of boron tifluoride etherate in the conversion of the alkenes into alcohols and subsequently their transformations into the terpenoid compounds.

\section{Cleavage of epoxides}

The epoxides can be cleaved by several reagents. The Lewis acid borontrifluoride etherate has also been used for the cleavage of epoxides and in many cases the resulting product rearranges to ketone. The cleavage of epoxides is also accompanied by cyclization. In this review the cleavage of some epoxides with boron trifluoride etherate and the use of the resulting products in the synthesis of natural products have been discussed.

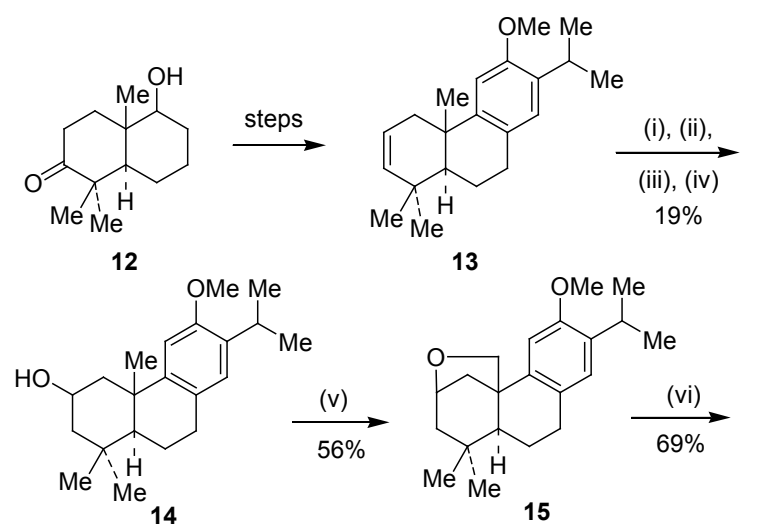<smiles>CC(C)c1cc2c(cc1O)C1(CO)CCCC(C)(C)C1CC2</smiles><smiles>COCC12CCCC(C)(C)C1CCC(C)c1cc(OC)c(C(C)C)cc12</smiles><smiles>CC(C)c1cc2c(cc1O)C1(C)CCCC(C)(C)C1CC2</smiles>

Scheme 4 Synthesis of pisiferic acid 18

Reagents: (i) $\mathrm{BF}_{3}$. $\mathrm{Et}_{2} \mathrm{O}, \mathrm{NaBH}_{4}$; (ii) $\mathrm{NaOH}(10 \%), \mathrm{H}_{2} \mathrm{O}_{2}(30 \%), \mathrm{H}_{2} \mathrm{SO}_{4}-\mathrm{HCrO}_{4}$; (iii) $\mathrm{LiAlH}_{4}, \mathrm{THF}$; (iv) $\mathrm{Pb}(\mathrm{OAc})_{4}, \mathrm{CaCO}_{3}, \mathrm{C}_{6} \mathrm{H}_{6}, 250$ w tungsten lamp; (v) $\mathrm{Zn}, \mathrm{Znl}$ $\mathrm{MeCOOH}$; (vi) $\mathrm{MeSO}_{4}, \mathrm{Me}_{2} \mathrm{CO}$; (vii) $\mathrm{H}_{2} \mathrm{SO}_{4}-\mathrm{HCrO}_{4}$; (viii) $\mathrm{CH}_{2} \mathrm{~N}_{2}, \mathrm{Et}_{2} \mathrm{O}$; (ix) $\mathrm{NaBH}_{4}, \mathrm{MeOH}$; (x) TsCl, Py; (xi) Nal, Zn dust, DMF; (xii) $\mathrm{AlBr}_{3},\left(\mathrm{CH}_{2} \mathrm{SH}\right)_{2}$.

\section{Synthesis of 6-methoxy-2-tetralone}

The cleavage of epoxide with boron trifluoride etherate has been utilized $^{13}$ for the synthesis of 6-methoxy-2-tetralone 20 (Scheme 5), an important selected starting material for the synthesis of many organic compounds. Epoxidation of the alkene ${ }^{13} 19$ followed by treatment of the crude product in dichloromethane with boron trifluoride etherate afforded the tetralone 20 in $36 \%$ yield. When the cleavage was tried 
with sulfuric acid the yield of the teralone 20 was improved (39\%) along with the formation of other secondary products and thus the chromatographic purification was very laborious.

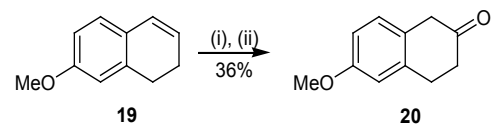

Scheme 5 Synthesis of 6-methoxy-2-tetralone $\mathbf{2 0}$ Reagents: (i) $\mathrm{MCPBA}, \mathrm{CH}_{2} \mathrm{Cl}_{2}$; (ii) $\mathrm{BF}_{3} \mathrm{OEt}_{2}$

\section{Synthesis of cuprane}

The rearrangement of epoxides by boron trifluoride etherate proved very useful during the synthesis ${ }^{14}$ of sesquiterpene cuprane. The synthetic route is described in Scheme 6. 6,6-dimethyl-1-ptolylcyclohexene 21 on epoxidation afforded the epoxide 22 in good yield which on treatment with boron trifluoride etherate in benzene yielded the aldehyde 23 in low yield. The semicarbazone of the aldehyde was heated with potassium hydroxide to furnish the sesquiterpene cuprane 24 in acceptable yield. The synthesis is attractive due to its brevity in steps. The conditions used for the rearrangement of the epoxide 22 are critical because it has the tendency to undergo further rearrangement to the ketone 25 .<smiles>[X]c1ccc(C2=CCCCC2(C)C)cc1</smiles>

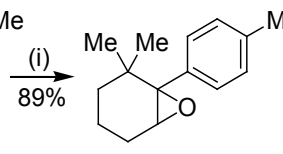

22

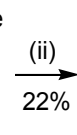<smiles>[M]c1ccc(C2(C)CCCCC2(C)C)cc1</smiles><smiles>Cc1ccc(C2CCCC(C)(C)C2=O)cc1</smiles>

25<smiles>Cc1ccc(C2(C)CCCC2(C)C)cc1</smiles>

24
Scheme 6 Synthesis of cuprane

Reagents: (i) $\mathrm{PhCO}_{3} \mathrm{H}, \mathrm{CHCl}_{3}$; (ii) $\mathrm{C}_{6} \mathrm{H}_{6}, \mathrm{BF}_{3} \mathrm{Et}_{2} \mathrm{O}$; (iii) $\mathrm{NH}_{2} \mathrm{NHCONH}_{2}, \mathrm{KOH}$

\section{Synthesis of $( \pm)$ karahana ether}

Boron trifluoride etherate was also used for the cleavage of epoxide during the synthesis ${ }^{15}$ of karahana ether, a volatile monoterpene which was isolated ${ }^{16}$ from Japanese hops. The synthetic route is described in Scheme 7. The epoxide 27, obtained from the diene 26, on being treated with boron trifluoride etherate underwent cyclization yielding the product 28. The cyclization probably occurred through the intermediate 27 (i). Metal hydride reduction afforded diol which on tosylation yielded karahanaether 29. The yield is unspecified. The cleavage of epoxides have been utilized for the synthesis of many terpenes like rosenolactone, ${ }^{17}$ cyperolone,${ }^{18}$ maritimol. ${ }^{19}$

\section{Esterification}

Esterification is a frequently used reaction for the synthesis of many organic compounds. Boron trifluoride etherate -alcohol is a very convenient reagent for the esterification of many p-amino benzoic acids, aromatic, heterocyclic and unsaturated acids. ${ }^{20}$ In some esterification reactions the use of this reagent provided superior yield compared with other reagents. Some examples are given in Scheme 8 . The acids 30-32 were converted to the esters 33-35 respectively in high yield on treatment with boron trifluoride etherate-alcohol reagent. Marshall and collaborators ${ }^{21}$ used the same reagent for the esterification of carboxylic acids. Dymicky ${ }^{22}$ prepared several formats in high yield from formic acid and alcohol in the presence of a catalytic amount of boron trifluoride -methanol complex. The other catalysts e.g. sulfuric acid, $p$-toluene sulfonic acid was not so efficient like boron trifluoride- methanol complex.<smiles>CC(=O)C=C(C=CCOC(C)=O)CCCC(C)(C)C(C)C</smiles>

26<smiles>C=C1CCC(O)C(C)(C)C1C(C)=O</smiles>

28 (iii), (iv)
$27 a$

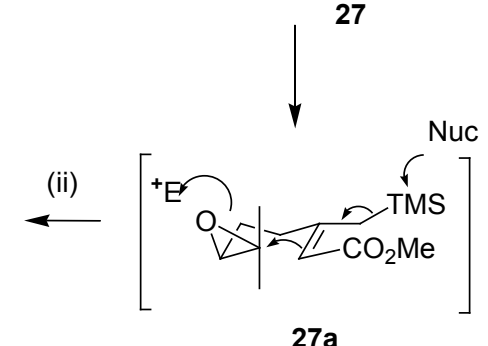

27<smiles>C=C1CCC2OC1C2(C)C</smiles>

29

Scheme 7 Synthesis of $( \pm)$ Karahana ether Reagents: (i) MCPBA; (ii) $\mathrm{BF}_{3} \mathrm{Et}_{2} \mathrm{O}$; (iii) $\mathrm{LiAlH}_{4}$; (iv) $\mathrm{TsCl}$, $\mathrm{Py}$<smiles>O=C(O)c1cc(O)ccc1O</smiles>

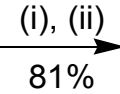

30<smiles>O=C(O)c1ccco1</smiles>

31<smiles>O=C(O)C1c2ccccc2Oc2ccccc21</smiles><smiles>C#CC1(S(=O)(=O)O)C=CCC1</smiles><smiles>CCOC(=O)C1c2ccccc2Oc2ccccc21</smiles>

35
Scheme 8 Esterification of acids 32-35

Reagents: (i) $\mathrm{MeOH}$; (ii) $\mathrm{BF}_{3} \cdot \mathrm{Et}_{2} \mathrm{O}$; (iii) $\mathrm{EtOH}$

Jackson and collaborators ${ }^{23}$ have developed an efficient method for the conversion of alcohols 37-39 and acids 40-42 directly to the corresponding t-butyl derivatives in good yield using t-butyl trichloroacetimidate 36 in the presence of a catalytic amount of boron trifluoride etherate as exhibited in Scheme 9. This method functions better with the acid sensitive groups than the traditional methods using isobutene. Less hindered hydroxyl group of a diol can be protected and also is amenable to small scale work (avoiding the handing of gaseous isobutene). The t-butyl 2,2,2-trichloroacetimidate 36 is 
readily prepared by the addition of t-butanol to trichloroacetonitrile. Most of the experiments were carried out in presence of a mixture of dichloromethane and cyclohexane. Acetic anhydride in presence of boron trifluoride etherate has been utilized for the of acetylation of hydroxyl group. ${ }^{24}$

\section{Cyclization}

The boron trifluoride etherate has played an important role in cyclization of many, carboxylic acids, allenes etc. The following few examples will illustrate the role of boron trifluoride etherate as cyclizing agent. The acid chloride 49 and alkene 50 were condensed to yield divinyl ketone ${ }^{25} 51$ which underwent Nazarov cyclization ${ }^{26,27}$ furnishing cyclic ketone 52 which was converted to the sesquiterpene trichodiene 53 (Scheme 10).

Scheme 9 Conversion of alcohols and acids from t-butyl derivatives. Reagents: 36, (i) $\mathrm{BF}_{3} \cdot \mathrm{Et}_{2} \mathrm{O}$, (ii) $\mathrm{CH}_{2} \mathrm{Cl}_{2}, \mathrm{C}_{6} \mathrm{H}_{12}$<smiles>CCCCC(=N)C(Cl)(Cl)Cl</smiles>

36

$\underset{37}{\mathrm{PhCH}_{2} \mathrm{OH}} \stackrel{36,(\mathrm{i}),(\mathrm{ii})}{\underset{72 \%}{\longrightarrow}} \underset{\mathbf{4 3}}{\stackrel{\mathrm{PhCH}_{2} \mathrm{OBu}^{\mathrm{t}}}{\longrightarrow}}$

$\begin{array}{ccc}\mathrm{Ph}\left(\mathrm{CH}_{2}\right)_{2} \mathrm{OH} & \text { 36, (i), (ii) } & \mathrm{Ph}\left(\mathrm{CH}_{2}\right)_{2} \mathrm{OBu}^{\mathrm{t}} \\ \mathbf{3 8} & 91 \% & \mathbf{4 4}\end{array}$

$\begin{array}{ccc}\mathrm{PhCH}(\mathrm{OH}) \mathrm{Me} & \stackrel{36,(\mathrm{i}),(\mathrm{ii})}{\longrightarrow} & \mathrm{PhCH}\left(\mathrm{OBu}^{\mathrm{t}}\right) \mathrm{Me} \\ 39 & 72 \% & 45 \\ \mathrm{PhCO}_{2} \mathrm{H} & \stackrel{36,(\mathrm{i}),(\mathrm{ii})}{\longrightarrow} & \mathrm{PhCO}_{2} \mathrm{Bu}^{\mathrm{t}} \\ \mathbf{4 0} & 92 \% & 46\end{array}$

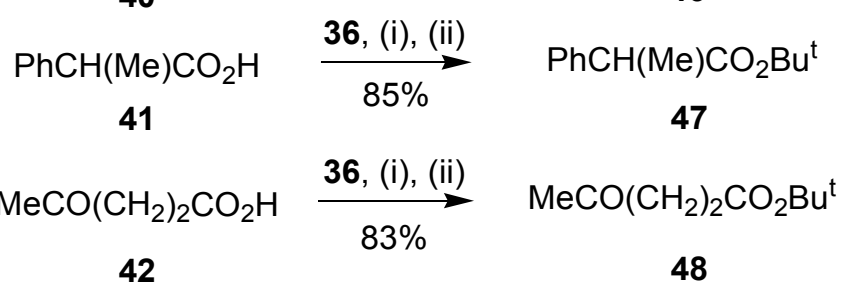

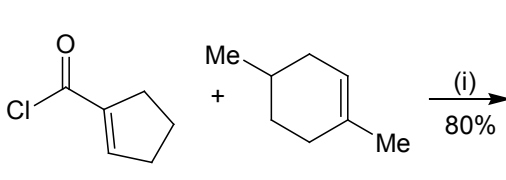

49

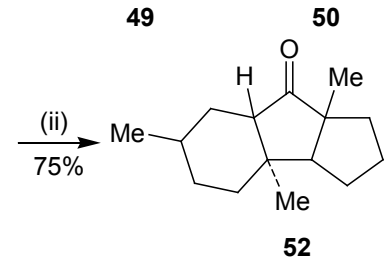

52<smiles>CC1=C(C(=O)C2=C(C)CCC(C)C2)CCC1</smiles>

51

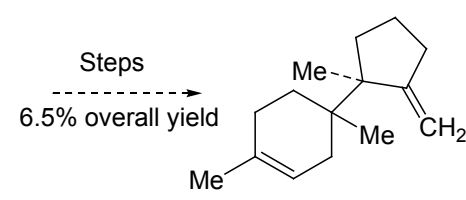

53 trifluoride etherate affording methylene benzocyclopentenone via a new 5-endo-mode cyclization. ${ }^{28}$ The ketones 54-56 afforded benzocyclopentenones 57-59 respectively (Scheme 11). Probably the transformation occurred as shown in the cyclization of allenyl aryl ketone 54 into 57 . It can be observed that the presence of substituent groups in aromatic ring determines the yield of the cyclized product. Kos and Loewenthal ${ }^{28}$ reported the cyclization of the acid 60 with boron trifluoride etherate to the ketone 61 which was converted gibberone 62 (Scheme 12) in three steps:

(i) Ketalization

(ii) Huang-Minlon reduction and

(iii) Acid hydrolysis. The above mentioned examples exhibit the use of boron trifluoride etherate in the cyclization of organic compounds

54<smiles>C=C1C=C([O-])C2=C([O-])C(=O)C(OC)=CC12C=CC</smiles>

i<smiles>C=C1C=C([O-])c2cc(OC)c(OC)cc21</smiles><smiles>C[PH2+]C</smiles><smiles>C=C1CC(=O)c2cc(OC)c(OC)cc21</smiles>
57<smiles>C=C=CC(=O)c1ccc2c(c1)OCO2</smiles><smiles>C=C1CC(=O)c2cc3c(cc21)OCO3</smiles>

58<smiles>C=CC=C(C(=O)c1cc(OC)cc(OC)c1)c1cc(OC)cc(OC)c1</smiles><smiles>C=C1CC(=O)c2cc(OC)cc(OC)c21</smiles>

59
Several allenyl aryl ketones undergo cyclization with boron<smiles>C=CC=C(C(=O)c1ccc(OC)c(OC)c1)c1ccccc1</smiles>

Scheme II Synthesis of Cyclopentenones<smiles>Cc1cccc2c1CC1(CC(=O)O)CC(C)C(=O)C=C21</smiles>

60

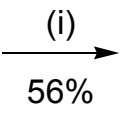

$\underset{18 \%}{\stackrel{\text { (ii), (iii), (iv) }}{\longrightarrow}}$<smiles>Cc1cccc2c1CC13CC(=O)C(C)(C1)C(=O)C=C23</smiles>

61
Scheme 12 Synthesis to gibberone Reagents: (i) $\mathrm{BF}_{3} . \mathrm{Et}_{2} \mathrm{O}$; (ii) (a) $\mathrm{C}_{2} \mathrm{H}_{6} \mathrm{O}_{2}$; (b) DEG, $\mathrm{N}_{2} \mathrm{H}_{4}, \mathrm{KOH}, 190-200^{\circ} \mathrm{C}$; (c) $\mathrm{H}^{+}$

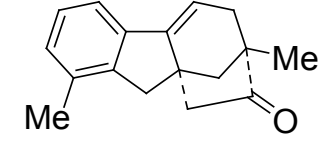

62 


\section{Miscellaneous uses}

In addition of the above mentioned reactions the following reactions also have been performed but not frequently employing boron trifluoride etherate.

\section{(A) Thioketalization and ketalization}

Thioketalization and ketalization reaction are very important reactions for organic synthesis. Some examples are given below. The acid 63 (Scheme 13) on esterification and thioketalization respectively afforded the compound 64 which on metal hydride reduction and acetylation respectively yielded the acetate 65 . The conversion of the acetate into the alcohol 66 was accomplished in three steps:
(a) Desulphurization
(b) Metal hydride reduction
(c) Catalytic hydrogenation

The alcohol 66 was utilized for synthesis 29 of kaurenediol 67.<smiles>COc1cccc2c1CC=C1C(C)(C)C(=O)CCC12CC(=O)O</smiles>

63

$$
\underset{79 \%}{\stackrel{\text { (i), (ii) }}{\longrightarrow}}
$$<smiles>COC(=O)CC12CCC3(SCCS3)C(C)(C)C1=CCc1c(OC)cccc12</smiles>

64

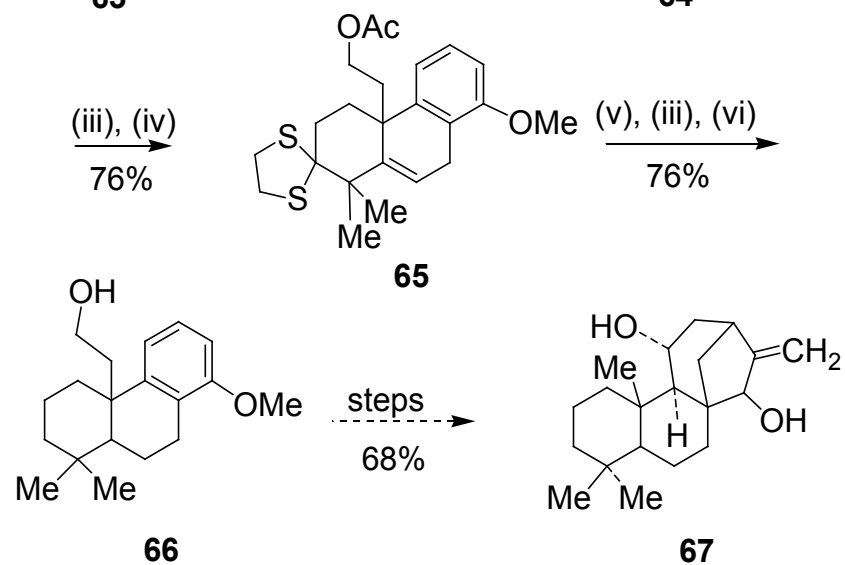

Scheme 13 Synthesis of Kaurenediol 67

Reagents: (i) $\mathrm{CH}_{2} \mathrm{~N}_{2}, \mathrm{Et}_{2} \mathrm{O}$, (ii) $\left(\mathrm{CH}_{2} \mathrm{SH}\right)_{2}, \mathrm{BF}_{3} \mathrm{OET}_{2}$, (iii) $\mathrm{LiAlH}_{4}, \mathrm{ET}_{2} \mathrm{O}$ (iv) $\mathrm{AC}_{2} \mathrm{O}, \mathrm{Py},(\mathrm{V}) \mathrm{Ra}-\mathrm{Ni}$, (vi) $\mathrm{H} 2,10 \% \mathrm{Pd} / \mathrm{C}$.

Thioketalization reaction was also applied ${ }^{30,31}$ for the synthesis of non-aromatic abietane type quinone royleanone which shows the cytotoxic activity against Eagle's KB strain of human carcinoma of the naso-pharynx. The synthetic route is described in (Scheme 14). The ketone 69 , prepared, from the ketone 68 , was subjected to thioketalization to obtain the compound 70 . Desulphurization followed by catalytic hydrogenation yielded 71 whose conversion to royleanone 72 was accomplished in three steps:

(i) Demethylation with boron tribromide

(ii) Heating the resulting compound in refluxing benzene with bubbling oxygen gas and

(iii) Isopropylation with isobutyryl peroxide in acetic acid. It is worthwhile to mention thioketalization reaction catalyzed by boron trifluoride etherate has also been applied for the synthesis of dehydroabietic acid by Stork and Schulberg, ${ }^{32}$ phyllocladene by Church and Ireland, ${ }^{33}$ Mori and Matsui, ${ }^{34}$ and many others. ${ }^{12}$<smiles>COc1cc(OC)c2c(c1OC)CCCC2=O</smiles>

68<smiles>COc1cc(OC)c2c(c1OC)CC=C1C2(C)CCC2(SCCS2)C1(C)C</smiles><smiles>[Y20]C1CCC2C(=O)C(C(C)C)=C(O)C(=O)C2C12CCCC2(C)C</smiles>

Scheme I4 Synthesis of non-aromatic abietane type quinone Reagents: (i) $\left(\mathrm{CH}_{2} \mathrm{SH}\right)_{2}, \mathrm{BF}_{3}$. Et ${ }_{2} \mathrm{O}$; (ii) Ra-Ni, boiling ethanol; (iii) $10 \%$ (Pd-C), $\mathrm{MeCOOH}$; (iv) $\mathrm{BBr}_{3}, \mathrm{CH}_{2} \mathrm{Cl}_{2}^{3}$; (v) $\mathrm{C}_{6} \mathrm{H}_{6}, \mathrm{O}_{2}$; (vi) $\left(\mathrm{MeCHCO}_{2}\right)_{2}$

Like thioketalization, boron trifluoride etherate has been used as catalyst for the reaction of ketones with oxirane to yield ketals. ${ }^{35}$ Thus the ketones (73-75) were converted to the ketals (76-78) respectively in high yield (Scheme 15). The use of epoxides for ketal formation offers the advantage of being extremely gentle, operating at room temperature and under protic conditions. Diethylene ortho carbonate converts ketones and aldehydes into their corresponding acetals in good yields at room temperature using slightly wet boron trifluoride etherate. ${ }^{36}$ It is particularly suitable for ortho-hydroxy aromatic aldehyde.<smiles>CC(C)(C)C1C[CH+]C(=O)CC1</smiles><smiles>CC(C)(C)C1CCC2(CC1)OCCO2</smiles>

73

76<smiles>O=C1CCCC1</smiles><smiles>C#CC1CO1</smiles><smiles>C1CCC2(C1)OCCO2</smiles>

74 77<smiles>C#CC1CO1</smiles>
75<smiles>C1CCCC2(CC1)OCCO2</smiles>

Scheme I 5 Synthesis of ketals from ketones (i) $\mathrm{BF}_{3} \cdot \mathrm{Et}_{2} \mathrm{O}, \mathrm{CH}_{2} \mathrm{Cl}_{2}, 25^{\circ} \mathrm{C}$. 


\section{(B) Molecular rearrangements}

Many organic compounds undergone transformation in presence of boron trifluoride etherate. The following examples illustrate the rearrangements originated by boron trifluoride etherate. The acetate 80 prepared from hydroxyl tetralin 79 underwent Fries rearrangement ${ }^{37}$ on heating at $125^{\circ} \mathrm{C}$ with boron trifluoride etherate in a microwave oven. The resulting tetrahydronaphthol ${ }^{38} 81$ (Scheme 16) was methylated to yield the compound 82 and finally converted to the already reported ${ }^{39}$ tetralone 83 (Scheme 16). Thus an alternative route ${ }^{38}$ was developed for the tetralone 83 which proved very useful for the synthesis ${ }^{39}$ of bioactive diterpene $(+)$ triptoquinone $\mathrm{A}$ and its analog $(+)$ triptin. Similarly, the Fries rearrangement with boron trifloride etherate was applied $^{40}$ to the acetate, prepared from the naphthol 84 . The compound 85 was treated with cerium ammonium nitrate (CAN) to obtain the quinone 86 . The quinone was utilized for the synthesis of eleutherins $\mathrm{s}^{40}$ 87 and isoeleutherin 88 (Scheme 16).<smiles>Oc1cccc2c1CCCC2</smiles>

79<smiles>COc1ccc2c(c1O)CCCC2</smiles>

81

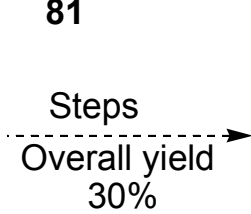

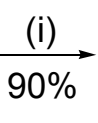<smiles>CC(=O)Oc1cccc2c1CCCC2</smiles>

80

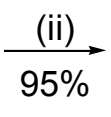<smiles>COc1c(C(C)=O)ccc2c1CCCC2</smiles>

82<smiles>[134I-]</smiles><smiles>COc1c(C(C)C)ccc2c1CCCC2=O</smiles>

83<smiles>COc1ccc(O)c2c(OC)cccc12</smiles>

84<smiles>CCCCCC(=O)c1cc(OC)c2cccc(OC)c2c1O</smiles>

85<smiles>COc1cccc2c1C(=O)C(C(C)C)=CC2=O</smiles>

Scheme 16 Synthesis of quinones from Naphthol

Reagents: (i) $\mathrm{Ac}_{2} \mathrm{O}$, $\mathrm{Py}$; (ii) $\mathrm{BF}_{3}$. $\mathrm{Et}_{2} \mathrm{O}$; (iii) $\mathrm{Me}_{2} \mathrm{SO}_{4}, \mathrm{Me}_{2} \mathrm{CO}$; (iv) $\mathrm{CAN}, \mathrm{MeCN}$

Matsumoto and collaborators ${ }^{41}$ reported a novel rearrangement of hydrophenanthhrene into hydroanthracene with boron trifluoride etherate. Thus the alcohol obtained by the metal hydride reduction of the enone 89 on treatment with boron trifluoride etherate suffered an interesting rearrangement yielding anthracene 90 . This method for the synthesis of anthracene was applied to the synthesis of biologically active linear abietane diterpenes. Deslongchamps ${ }^{42}$ reported a very interesting rearrangement of diketone 91 to 8-acetoxy-4-twistanone 92 on treatment with a mixture of acetic acid, acetic anhydride and boron trifluoride at room temperature. The compound 92 is the first twistane derivative having a functional group at a bridge position (Scheme 17).<smiles>CC(=O)c1cccc2c1C(=O)C=C1C(C)(C(C)=O)CCCC12C</smiles>

89<smiles>O=C1CCC2CCC(=O)CC2C1</smiles>

91<smiles>COC(=O)C1(C)CCCc2c1cc1cc(C([18O])[18F])ccc1c2C</smiles>

90

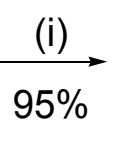<smiles>CC(=O)OC12CCC3CC4CC(=O)C1C342</smiles>

92
Scheme 17 Rearrangement of diketones

Reagents: (i) $\mathrm{AcOH}, \mathrm{Ac}_{2} \mathrm{O}, \mathrm{BF}_{3} \cdot \mathrm{OEt}_{2}$

Srikrishna and collaborators ${ }^{43}$ reported one-step method for the conversion aryl ketones into the corresponding hydrocarbons by stirring with sodium cyanoborohydride in presence of two to three equivalents of boron trifluoride etherate. Thus the ketones (9395) were converted into the corresponding hydrocarbons (96-98) respectively in high yield. These reactions were conducted at room temperature. High temperature was also used for the deoxygenation of some aryl ketones e.g. (99-101) into the hydrocarbons (102-104) respectively (Scheme 18).

A mixture of boron trifluoride etherate and acetic anhydride at $0^{\circ}$ or below has been found to cleave different types of steroidal methyl ethers. ${ }^{44}$ Allylic and homoallylic ethers give the corresponding acetates in high yield. The completely saturated ethers give the acetate with retention of configuration as the main substituent product, but the epimeric acetate and elimination products are also obtained. A very interesting result was obtained when the demethylation experiment was tried with 4,8-dimethoxy-1-tetralone ${ }^{45} 105$ with boron trifluoride etherate and acetic anhydride. The tetralone underwent aromatization yielding the acetate 106 not the expected acetate107 (Scheme 19). On similar treatment the tetralone 108 afforded the acetate 109 . These observations did not agree with the reported observation of Narayanan and Iyer on steroidal ethers. ${ }^{44}$

One of the most interesting applications of boron trifluoride etherate consists in the unprecedented alkylation of carboxylic acids 
in the absence of alcohols. ${ }^{46}$ Many aromatic and aliphatic carboxylic acids were readily alkylated in short time. It was also observed that ortho-substituted hydroxyl groups of carboxylic were not affected by alkylation but those of Meta-and para-substituted carboxylic acids were partially etherified. In addition alkylation reaction was carried out in presence of several functional groups such as halogens, amino and nitro groups. Some examples are given below (Scheme 20). Thus the acids (110-112) were alkylated to obtain the alkylated products (113-115) respectively.<smiles>CC(=O)c1ccc(O)cc1</smiles>

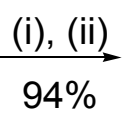

93<smiles>COc1ccc(C(C)=O)cc1</smiles>

94<smiles>CC(=O)c1ccc(OP)cc1</smiles><smiles>[113OH]</smiles><smiles>O=C(c1ccccc1)c1ccccc1</smiles>

99<smiles>Cc1ccc(C(=O)c2ccccc2)cc1</smiles>

100<smiles>Cc1ccc2c(c1C)CCC2=O</smiles>

101

\section{(i), (ii) $71 \%$}<smiles>CCc1ccc(OC)cc1</smiles>

97<smiles>Cc1ccc(O)cc1</smiles>

98

$$
\underset{88 \%}{\stackrel{(i),(\text { iv) }}{\longrightarrow}}
$$

$\stackrel{(i),(v)}{\longrightarrow}$ $84 \%$

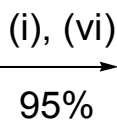<smiles>Cc1ccc2c(c1[N+](=O)[O-])CCC2</smiles>

Scheme 18 Conversion of the aryl ketones into the corresponding hydrocarbons

Reagents: (i) $\mathrm{NaCNBH}_{3}, \mathrm{BF}_{3} . \mathrm{OEt}_{2}$; (ii) RT, $12 \mathrm{~h}$; (iii) $\mathrm{RT}, 8 \mathrm{~h}$; (iv) $65^{\circ} \mathrm{C}, 8 \mathrm{~h}$; (v) $65^{\circ} \mathrm{C}$, h; (vi) $65^{\circ} \mathrm{C}, 4 \mathrm{~h}$.

\section{Conclusion}

This mini review focuses some of the applications of the boron trifluoride etherate in organic synthesis. The use of boron trifluoride etherate would continue owing to its operational simplicity and low cost. We believe the many of the above mentioned reactions could not have been accomplished without boron trifluoride etherate. Some of the products mentioned above have received use in natural product synthesis. It is necessary to indicate that many important applications of boron trifluoride etherate have been omitted in this review due to the limitation of space. We are sure that the information's discussed

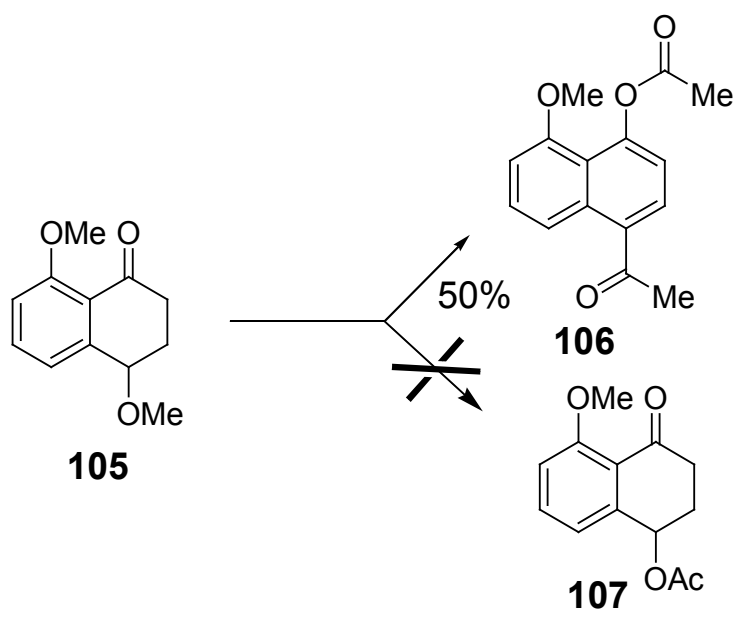<smiles>COc1ccc2c(c1)C(C)CCC2=O</smiles>

Scheme 19 Aromatization of tetralones Reagents: $\mathrm{BF}_{3}, \mathrm{Et}_{2} \mathrm{O}, \mathrm{Ac}_{2} \mathrm{O}$<smiles>O=C(O)c1ccccc1</smiles><smiles>C[13CH]</smiles><smiles>CCOC(=O)c1ccccc1</smiles>

110 113<smiles>O=C(O)c1ccc(Cl)cc1</smiles><smiles>CC(C)(C)O</smiles><smiles>CCOC(=O)c1ccc(Cl)cc1</smiles><smiles>Nc1ccc(C(=O)O)cc1</smiles><smiles>C#CCCCCCC</smiles><smiles>CCOC(=O)c1ccc(N)cc1</smiles>

Scheme 20 Alkylation reaction Reagents: (i) $\mathrm{BF}_{3} . \mathrm{OEt}_{2}$, Reflux

would serve the need of organic chemists engaged in searching new applications of boron trifluoride etherate in organic synthesis.

\section{Acknowledgments}

The authors gratefully acknowledge the receipt of the reprint on alkylation from Dr. Wayiza Masamba, Department of Chemical and Physical Sciences, Walter Sislu University, Nelson Mandela Drive, South Africa and collaboration of Mr. José Gregorio, Bibleoteca IVIC, Caracas Venezuela for literature references. 
Po S. Poon also thanks CONICYT PIA/APOYO CCTE AFB170007 and CONICYT FONDECYT 1161068.

\section{Conflicts of interest}

Authors declare that there is no conflict of interest.

\section{References}

1. Coronel V. Encyclopedia of Reagents for Organic Synthesis. Paquette LA, editor. New Jersey: John Wiley \& Sons Ltd. 1999;664-673.

2. Fieser L, Fieser M. Reagents for organic synthesis. 2005;1(22).

3. Banerjee AK, Hurtado HE, Carrasco MC. Synthetic studies on terpenoids. Part 7. Synthetic studies leading to the total synthesis of eudesmane sesquiterpenes. Journal of Chemical Society, Perkins Transactions.1982;2547-2551.

4. Bowers A, Halsall TG, Jones ERH, et al. Chemistry of triterpenes and related compounds. Elucidation of the structures of polyporenic acid C. Journal of Chemical Society. 1953;2548-2560.

5. Nakano T, Banerjee AK. Studies on the potential intermediates for the syntheses of rosane type diterpenoids: Preparation of $8 \beta$-acetoxymethyl$2 \beta$-acetoxy-4a $\beta, 8$-dimethyl-1,2,3,4,4a,4b $\alpha, 5,6,7,8,10,10 \mathrm{a} \alpha$ dodecah ydrophenanthrene and $8 \beta$-carboxy-2 $\beta$-benzoyloxy-4a $\beta, 8$-dimethyl9-keto-trans, anti,trans perhydrophenanthrene. Tetrahedron. 1972;28(3):471-480.

6. Banerjee AK, Hurtado H, Laya M, et al. Total synthesis of ( \pm ). Journal of Chemical Society, Perkins Transactions. 1988;4:931-938.

7. Fukui H, Koshimizu K, Egawa H. Anew diterpene with antimicrobial activity from Chamaecyparis pisifera Endle. Agricultural \&Biological Chemistry. 1978;42(7):1419-1423.

8. Fujimoto $\mathrm{Y}$, Miura $\mathrm{H}$, Shimizu T, et al. Modification of $\alpha$-santonin VI. Synthesis of (+)-deoxyvernolepin. Tetrahedron Letters. 1980;21(35):3409-3412.

9. Banerjee AK, Caraballo PC. Total synthesis of ( \pm )-Eudes-ma4(14),7(11)-diene-8-one. Indian Journal of Chemistry. 1983;22B: $1259-1260$.

10. Banerjee AK, Carrasco MC. Synthetic Approaches to ( \pm )-Taxodiones. Synthetic Communications. 1983;13(4):281-287.

11. Banerjee AK, García WF. Total synthesis of Norditerpene Alcohols. Synthetic Communications. 1980;10(9):693-698.

12. Goldsmith D. Total Synthesis of Natural Products. John Wiley \& Sons Inc. 1992;8:1-309.

13. Da Silva J, Bedoya L, Arrieche DA, et al. A Concise Approach for the synthesis of 6-Methoxy-2-Tetralone. MOJ Bioorganic \& Organic Chemistry. 2018;2(1):32-34.

14. Bird CW, Yeong YC. A new approach to the synthesis of $( \pm)$-cuparene. Synthesis. 1974;(1):27-28.

15. Armstrong RJ, Weiler L. Synthesis of $( \pm)$-Karahana ether and a $( \pm)$-labdadienoic acid by the electrophilic cyclization of epoxy allylsilanes. Canadian Journal of Chemistry. 1986;64(3):584-596.

16. Naya Y, Kotake M. New monoterpenoids from hop oil. Tetrahedron Letters. 1968;9(13):1645-1648.

17. Hancock WS, Mander LN, Massy-Westropp RA. Synthesis of rosenonolactone from podocarpic acid. $J$ Org Chem. 1973;38(23):4090-4091.

18. Hikino H, Suzuki N, Takemoto T. Synthesis of Cyperolone. Chemical and Pharmaceutical Bulletin. 1966;14(12):1441-1443.

19. Van Tamelen EE, Carlson JG, Russell RK, et al. Total synthesis of ( \pm )-Maritimol. J Am Chem Soc. 1981;103(15):4615 -4616.

20. Kadaba PK. Boron trifluoride etherate-alcohol, a versátil reagent for the esterification reaction. Synthetic Communications. 1974;4(3):167-181.
21. Marshall JL, Erickson KC, Folsom TK. The esterification of carboxylic acids using a boron trifluoride-etherate-alcohol reagent. Tetrahedron Letters. 1970;11(46):4011-4012.

22. Dymicky M.Ageneral method from the preparations of formates. Organic Preparations and Procedures International. 1982;14(3):177-181.

23. Armstrong A, Brackenridge I, Jackson RFW, et al. A new method for the preparation of tertiary butyl ethers and esters. Tetrahedron Letters. 1988;29(20):2483-2487.

24. Nagao Y, Fujita E, Kohno T, et al. An efficient method for selectived acetylation of alcoholic hydroxyl groups. Chemical Pharmaceutical Bulletin. 1981;29(11):3202-3207.

25. Harding KE, Clement KS, Tseng CY. Stereoselective synthesis of ( \pm )-trichodiene. J Org Chem. 1990;55(14):4403-4410.

26. Santelli-Rouvier C, Santelli M. The Nazarov Cyclisation. Synthesis. $1983 ; 6: 429-432$.

27. Nagao Y, Lee WS, Kim K. New intramolecular Five-EndoMode Cyclization of allenyl aryl ketones. Chemistry Letters. 1994;23(2):389-392.

28. Kos Y, Lowenthal HJE. Synthesis of compounds related to gibberelic acid. Part. I. ( \pm )-Gibberone. Journal of the Chemical Society. $1963 ; 605-611$.

29. Fujita E, Ochiai M. Terpenoids. XLIII. Total synthesis of rac-Kaur-16-

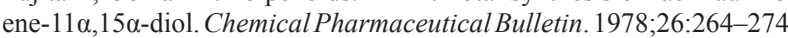

30. Matsumoto T, Tachibana Y, Fukui K. The synthesis of ( \pm )-Royleanone. Chemistry Letters. 1972;1(4):321-324.

31. Tachibana Y. The total synthesis of $( \pm)$-Royleanone. Bulletin of the Chemical Society Japan. 1975;48(1):298-301.

32. Stork G, Schulenberg JW. The total synthesis of dl-Dehydroabietic acid. J Am Chem Soc. 1956;78(1):250-251.

33. Church RF, Ireland RE, Marshall JA. Experiments direct toward the Total synthesis of terpenes. VII. The synthesis of $( \pm)-8 \beta$-Carbomethoxy13-oxopodocarpanone, a Degradation product of Phyllocladene1. J Org Chem. 1966;31(8):2526-2530.

34. Mori K, Matsui M. Diterpenoid Total synthesis-VIII: ( \pm )-Kaur-16en-19-oic acid, ( \pm )-Kaur-16-en-19-ol, $( \pm)$-Monogynol and some oxygenated kauranes. Tetrahedron. 1968;24(7):3095-3111.

35. Torok DS, Figueroa JJ, Scott WJ. 1,3-Dioxolane formation via lewis acid-catalyzed reaction of ketones with oxiranes. Journal of Organic Chemistry. 1993;58(25):7274-7276.

36. Barton DHR, Dawes CC, Magnus PD. A new acetalisation reagent: ethyleneorthocarbonate. $J$ Chem Soc Chem Commun. $1975 ;(11): 432-433$.

37. Belluc D, Hrdlovic P. Photochemical Rearrangement of aryl, vinyl and substituted vinyl esters and amides of carboxylic acids. Chem Rev. 1967;67(6):599-609.

38. Vera WJ, Banerjee AK. Synthesis of 5-Methoxy-6-Isopropyl-1tetralone. Nat Prod Commun. 2016;11(5):671-672.

39. Basil LF, Nakano H, Frutos R, et al. Asymmetric tandem Additions to chiral 2,3 dihydronaphthyoxazolines: Synthesis of the Triptoquinone/ Triptinin A Ring system. Synthesis. 2002;14:2064-2074.

40. Naruta Y, Uno H, Maruyama K. Synthesis of ( \pm )-eleutherin, $( \pm)$-isoeleutherin and their demethoxy analogues. A novel synthetic approach. J Chem Soc Chem Commun. 1981;(24):1277-1278.

41. Matsumoto T, Takeda Y, Soh K, et al. Skeletal rearrangement of the Dehydroabietic acid derivative. Bulletin of the Chemical Society of Japan. 1995;68(8):2349-2353.

42. Belanger A, Poupart J, Deslongchamps P. A one-step synthesis of the twistane ring system 8-acetoky-4-twistanone. Tetrahedron Letters. 1968;9(17):2127-2128. 
43. Srikrishna A, Sattigeri A, Viswajanni RV, Yelemagged CV. A simple and convenient one step method for the reductive Deoxygenation of ary ketones to hydrocarbons. Synlett. 1995;1:93-94.

44. Narayanan CR, Iyer KN. Regeneration of steroids alcohol from their methyl ethers. J Org Chem. 1965;30(6):1734-1736.

45. Banerjee AK, Bedoya L, Vera WJ, Melean C, Mora H, Laya MS,
Alonso M. Novel transformation of Methoxy tetralones during demethylation with boron trifluoride etherate and acetic anhydride. Synthetic Communications. 2004;34(18):3399-3408.

46. Jumban ND, Maganga Y, Masamba W, Mbunye NI, Mgoqi E, Mtwa S. Unprecedented alkylation of carboxylic acids by boron trifluoride etherate. Bulletin of the Chemical Society of Ethiopia. 2018;32(2):387-392. 